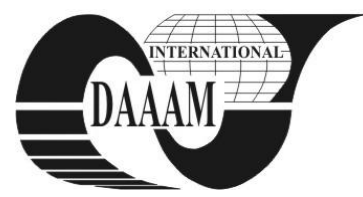

Annals of DAAAM for 2011 \& Proceedings of the 22nd International DAAAM Symposium, Volume 22, No. 1, ISSN 1726-9679 ISBN 978-3-901509-83-4, Editor B. Katalinic, Published by DAAAM International, Vienna, Austria, EU, 2011 Make Harmony between Technology and Nature, and Your Mind will Fly Free as a Bird

\title{
STUDY ON CORPORATE GOVERNANCE SYSTEM ARCHITECTURE
}

\author{
BRANDAS, C[laudiu] \& OCNEAN, M[onica]
}

\begin{abstract}
Corporate Governance is based on a complex system of relationships between shareholders, managers, auditors and stakeholders based on decision-making processes, codes of good practice, procedures and technologies. To ensure effective and efficient corporate governance in order to increase corporate performance and stability on the capital market and in society is necessary to analyze the architecture of governance systems especially the decision-making process. The purpose of this study is to analyze and model corporate governance systems architecture and identify the actors, processes and relationships within these systems in order to optimize them.
\end{abstract}

Key words: corporate governance, architecture, process, performance, information systems

\section{INTRODUCTION}

The major problem of corporate governance systems is to eliminate the problems generated in agency relationship and the phenomenon of information asymmetry between internal and external corporate actors, by increasing transparency of decision-making processes and accountability of management.

In figure 1 we present the way the information is concentrated within the decision-making process of the company, mainly on the management and the board of directors, highlighting the information asymmetry between those involved in company governance. Thus, for the best governance, the shareholders need quality and accurate information in real time. Most of the times, this information is controlled by the management (the agent) generating information asymmetry (Akerlof, Spence \& Stiglitz, 2001) between the two parties.

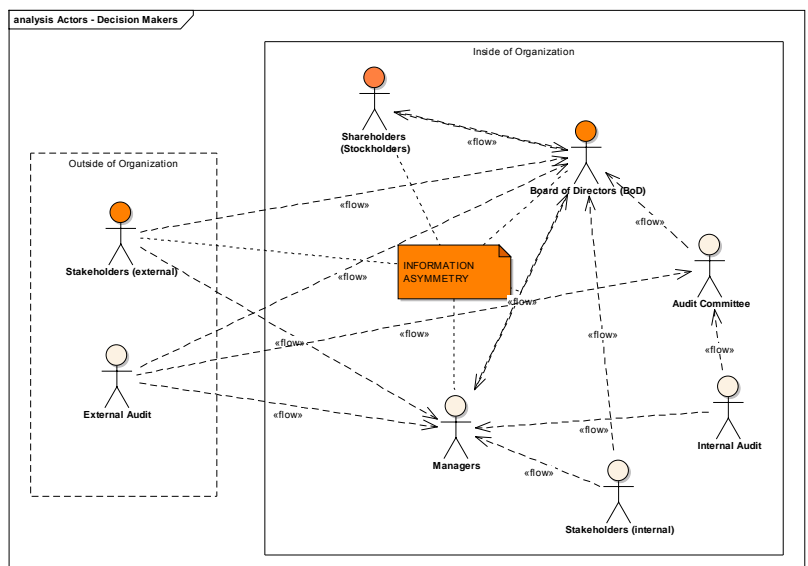

Fig.1. Information flows asymmetry in corporate governance system

\section{RESEARCH METHODOLOGY}

The research that has been done is based on an analytical study of the published works (articles and books) from 2001 to
2011 in the area of corporate governance, based on the following search key words: corporate governance systems, corporate governance architecture, corporate governance process, corporate governance actors. We extract data for our research from the following data bases: ScienceDirect, ProQuest, Emerald, SpringerLink, Wiley Online Library and EBSCO.

\section{ARCHITECTURE OF CORPORATE GOVERNANCE SYSTEMS}

As a result of our research, we obtained and propose a architecture of corporate governance systems. The corporate governance system could be viewed as a complex system of rules, procedures, monitoring and assessment methods, processes and relationships between the actors of the system (Bushman et al., 2004).

Also, this system is focused exclusively on decisionmaking processes and information flow between the shareholders, the board of directors, the audit committees, stakeholders and the management. Within this system, there can be identified a series of interest groups that hold different roles in company governance (OECD, 2004), (Bourse de Luxembourg, 2009), (Institute of Directors, 2009).

These groups interact within certain complex processes that could affect company performance and its position on the stock market.

A possible issue regarding the optimal integration and functioning of these processes is that of information support. For good corporate governance, both actors and processes need an integrated information support that processes and offers the most accurate information in real time, to all decision-making factors within the corporate governance systems (Lazarides \& Drimpetas, 2008). This support must be into a collaborative manner.

By analyzing literature, both the American Model (AngloSaxon) and the Continental Model (German and Japanese) on corporate governance, we summarized it in Table 1 by presenting the base actors and the processes of corporate governance (Hill, 2010), (Ghita et al., 2009), (Spencer Pickett, 2006), (IIA, 2004), (Maassen, 2002).

In order to highlight the information flow between the actors and the processes within corporate governance, we develop the use cases diagram (figure 2).

We can clearly observe in this diagram the interactions on the flow of input and output between the processes and the actors.

The architecture of the corporate governance systems is very complex and its foundation is based on one hand on heterogenic information (codes of good practice, performance indicators, scores), and on the other hand the decision-making processes and the decision-makers, which are very difficult to integrate. 


\begin{tabular}{|c|c|c|}
\hline \multirow[t]{2}{*}{ ACTORS } & internal & $\begin{array}{l}\text { - Shareholders (Stockholders) } \\
\text { - Board of Directors (BoD) } \\
\text { - Managers } \\
\text { - Executive Directors } \\
\text { - Non-executive Directors } \\
\text { - Audit Committee } \\
\text { - Internal Auditors } \\
\text { - Employees }\end{array}$ \\
\hline & external & $\begin{array}{l}\text { - Investors (Financial Markets) } \\
\text { - External Auditors } \\
\text { - Banks } \\
\text { - Suppliers and Customers } \\
\text { - Governments }\end{array}$ \\
\hline \multicolumn{2}{|l|}{ PROCESS } & $\begin{array}{l}\text { - Risk Management } \\
\text { - Internal Control } \\
\text { - Internal Audit } \\
\text { - External Audit } \\
\text { - Development and Analysis of the companz } \\
\text { performance indicators } \\
\text { - Corporate Governance Metrics development } \\
\text { and analysis }\end{array}$ \\
\hline
\end{tabular}

Tab. 1. Actors and base process of corporate governance system

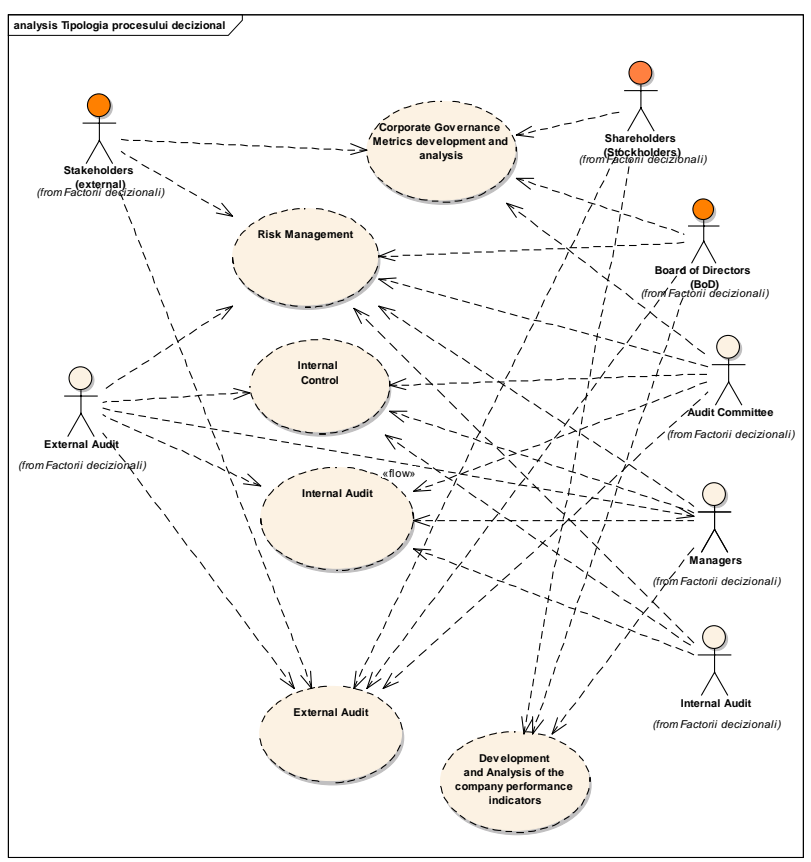

Fig. 2. Main process of corporate governance system

The optimization of corporate governance processes, so that they will be more efficient and effective, could be achieved only through a hybrid and integrated information system based on complex systems and technologies for the decision-making support (Filip, 2008).

Without a flexible and efficient information system, the corporate governance will be more a governance mechanism based only on trust and reputation (Lazarides \& Drimpetas, 2008).

The problem of the governance mechanism based on trust and reputation is given by the fact that the input, the processes and the output are not explicitly and transparently determined.

Therefore, through the integrated use and in collaborative manner of the information technology within the corporate governance, the governance mechanisms will become more efficient and effective.

\section{CONCLUSION}

Corporate governance involves a complex information and decision-making system, based on decision-making processes distributed among different users and decision-makers both inside and outside the organization.

The architecture of corporate governance systems is a very complex one, which involves a series of actors, decisionmaking and transactional processes, technologies, procedures and good practice codes.

In order to ensure the efficiency and efficacy of corporate governance as a premise for increasing company's performance and consolidation their position on the capital market an society, it is necessary to analyze the architecture of corporate governance systems.

Corporate governance systems architecture study is an important and indispensable for the development of efficient and effective enterprise systems in the context of good corporate governance. It is important to know and abstractization the role of each actor and process structure involved in corporate governance to increase effectiveness and efficiency of these systems in terms of using information technology. An effective corporate governance based on existing information technology used inside or outside the corporation can lead to a stable position of the companies on the capital market and society.

As a future research the architecture of corporate governance systems can constitute the starting point for modeling new enterprise information systems for support corporate governance.

\section{ACKNOWLEDGEMENTS}

This paper is part of the research project POSDRU/89/1.5/S/59184 "Performance and excellence in postdoctoral research within the field of economic sciences in Romania", Babeş-Bolyai University, Cluj-Napoca being a partner within the project.

\section{REFERENCES}

Akerlof, G.A.; Spence, A.M. \& Stiglitz, J.E. (2001) Markets with Asymmetric Information, Committee, Nobel Prize

Bushman, R., Chen, Q., Engel, E. \& Smith, A. (2004) Financial accounting information, organiza-tional complexity and corporate governance systems, Journal of Accounting and Economics, 37(2), pp. 167-201

Filip, F.G. (2008). Decision support and control for large-scale complex systems, Annual Re-views in Control, 32, pp. 6170

Ghita, M. et al. (2009). Guvernanta Corporativa si Auditul Intern, Ed. Mirton, Timişoara

Hill, J.G. (2010). The Architecture of Corporate Governance in Australia, ECGI

Kaplan, R.S. \& Nagel, M.E. (2003). Improving Corporate Governance with the Balanced Scorecard, Working Paper, Harward Business School

Lazarides, T. \& Drimpetas, E. (2008). The missing link to an effective corporate governance system, Corporate Governance, 8(1), pp. 73-82

Maassen, G.F. (2002). An International Comparison of Corporate Governance Models, 3rd edition, SpencerStuart.

Spencer Pickett, K.H. (2006). The Internal Auditing Handbook, Second Edition, John Wiley \& Sons, NY

*** (2009) Bourse de Luxembourg, Corporate Governance The Ten Principles of Corporate Governance of the Luxembourg Stock Exchange

*** (2004) IIA, UK and Ireland., Position Statement - The Role of Internal Audit Enterprise-Wide Risk Management

*** (2009) Institute of Directors, The handbook of international corporate governance: a defini-tive guide, Kogan Page, London

*** (2008) KPMG, Improving governance with XBRL, 2008

*** (2004) OECD, Principles of Corporate Governance 